\title{
Quality Input of Academic Literacy Competencies in Indonesian Language and Literature Students in Universitas Negeri Semarang
}

\author{
Diah Puspitaningrum $^{1}$, Ida Zulaeha ${ }^{2}$, Wagiran ${ }^{3}$ \\ \{diah.pus12@gmail.com¹, idazulaeha@mail.unnes.ac.id², wagiranunnes@mail.unnes.ac.id $\left.{ }^{3}\right\}$ \\ Graduate School of Semarang State University \\ Jalan Kelud III, Petompon, Gajahmungkur, Semarang City, Indonesia
}

\begin{abstract}
The industrial revolution 4.0 is a matter of rapid and fundamental change. Academic literacy competency is one of the competencies that must be possessed by students. This study aims to evaluate the quality of input of academic literacy competencies of Indonesian Language and Literature Department students at Semarang State University. The approach used is evaluative research by analyzing data using qualitative description analysis. This study resulted in the findings of the quality input of academic literacy competencies students got a score of 69.5 with sufficient categories. The conclusion of this study is the quality of input of academic literacy competencies based on internal and external aspects of students and lecturers. This research contributes in providing evaluation of programs owned by individuals to be able to give consideration to change and improvement in improving student academic literacy competencies.
\end{abstract}

Keywords: input quality, academic literacy competencies

\section{Introduction}

Literacy activities become one of the keys to the progress of a country's civilization. One of the keys to literacy is language literacy. The definition of literacy which means that literacy is the ability to read or write[1]. Based on the context of its use stated that literacy is the integrity of listening, speaking, writing, reading, and critical thinking skills. Literacy is the answer to global competition in accordance with the 2015 World Economic Forum annual report. Changes that occurred in the era of industrial revolution 4.0 were fast and had to be dealt with quickly too. Various sectors of life are no exception to education, requiring adjustments that are responsive to the phenomenon.

Lecturers and students have their respective roles in running education at the college level. Lecturers who are adaptive to change are lecturers who will survive, including changes in information and communication technology in lectures[2]. Based on the research conducted the reading culture observation conducted at Semarang State University, especially in The Language and Art Faculty has not shown results as expected due to the limitations of the reading environment and students' reading habits are limited to reading at a glance[3]. The study found that students' creative reading skills were still at 74.23. The results obtained are in the good value range but are still at a low yield.

Academic literacy competencies must be developed from many parties so that students are accustomed to making a work on the basis of searching for themselves by reading and writing 
themselves according to their ideas. Therefore, it is necessary to know what components should be considered to improve literacy culture in accordance with the Indonesian context[4].

Academic literacy is Integral to disciplinary literacy and academic success is the mastery of academic language therefore a discipline has a need for precision through its texts or its language[5]. The quality of students' academic literacy competencies will affect the quality of graduates who will face all the problems of the times. If not done by students and graduates, they will find it difficult to be able to follow all developments that always arise and run very fast.

\section{Research Method}

This research is a type of evaluative research. The stages carried out in this study are planning, data collection and data analysis, as well as the preparation of research results. The subject of this study will be limited to students of the Indonesian Language and Literature Department of Semarang State University as a sample of the application of language skills in the realm of academic competence. The sample was taken by 120 students who will be divided into 40 first-year semester students, 40 second-year semester students, and 40 third-year semester students.

Data collection is done in four ways, namely questionnaire techniques, interviews, and observation. The data taken in this study is in the form of data on student perceptions of academic literacy competencies. The data analysis technique used is by using the CIPP evaluative method, namely by changing the quantitative data taken from the questionnaire then cumulative and averaged according to the aspects of the discussion into qualitative data that describes the quality, constraints, and solutions that can give results on the program evaluation whether run optimally and the model used can continue to be implemented or not and needs to be changed.

\section{Results and Discussion}

Input evaluation is carried out to identify and assess the capabilities of material, tool, human and cost resources, to implement the chosen program[6]. Another opinion conveyed that input quality is everything that must be available because it is needed for the ongoing educational process that includes human resources, device input, and expectation input. The following are the results for aspects of the role of the lecturer, self-habituation, and reciprocal giving of lecturers can be seen in figure 1. 


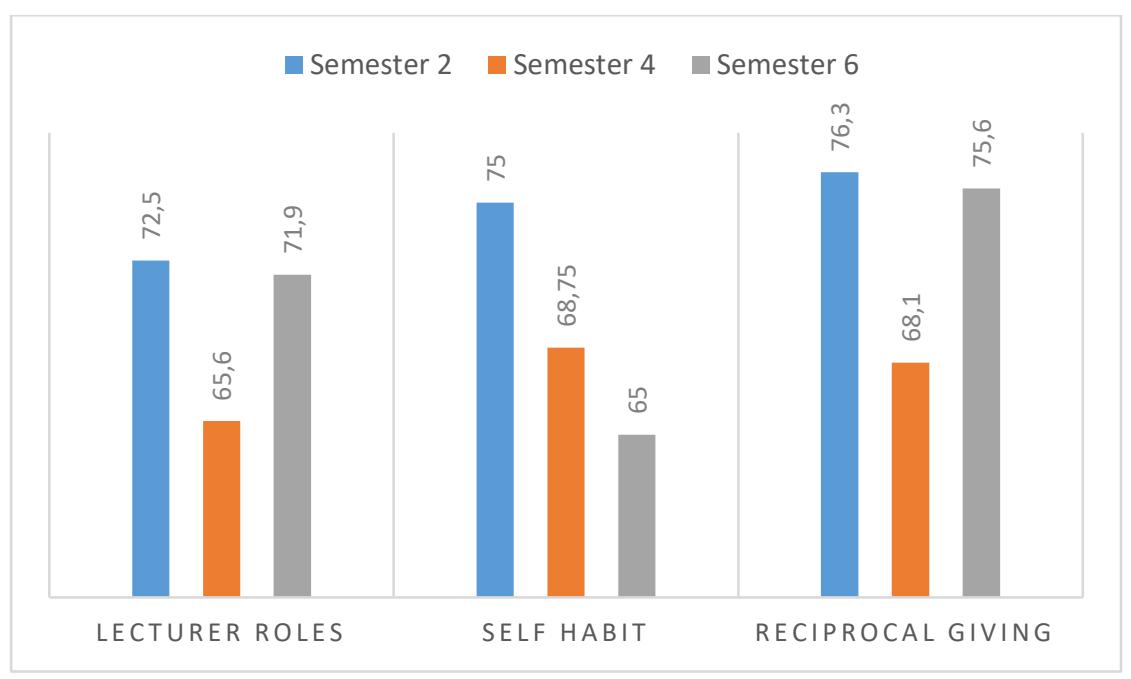

Figure 1. Data Results of Aspects of Lecturer Roles, Self Habit, and Reciprocal Giving

From the figure 1 get results on the aspect of the role of the lecturer in habituating the use of academic literacy competencies with the highest quality in semester 2 students score 72.5 and the average score 70. Constraints found in these aspects are habituation done by lecturers not yet regularly carried out each lecture. The habit of using academic literacy competencies in the lecture process and when working on assignments must be carried out intensively to get a good quality of academic literacy competencies. In the lecture process, lecturers and students play a role in each other to work together to achieve the objectives of the lecture that has been formulated. The role of the lecturer in self-habituation can trigger one of the basic basic characteristics of competence, namely trait, which is a tendency to consistently respond to situations or information received by individuals.

In the habitual aspect of self to improve academic literacy competencies, the highest score was 75 for second semester students with an overall average score of 69.6. This self-habituation aspect is carried out alone and independently by students. The habit of self to improve reading and writing skills is done in the presence of self motivation. The overwhelming burden of assignments is considered not to provide an opportunity to familiarize themselves in improving their reading and writing skills independently in accordance with what they like. This makes the arrangement of distribution of activities limited, reading and writing activities are only carried out according to the needs of the task. Reading learning is very important for students at the university because it requires them not only to read in detail but also to understand comprehensively[7].

In the aspect of reciprocal giving from lecturers to literacy activities in the lecture the highest score was 76.3 with an average score of 73.3. Constraints found in this aspect are reciprocal giving by lecturers to literacy activities that have not been carried out intensively and continuously. To be able to apply and improve academic literacy competencies, the process carried out after self-habituation is a process of reciprocal giving. One level of literacy is involving collaboration, namely there is cooperation between two parties, namely between the reader and the listener. The reciprocal giving of lecturers will create a good social system for students. The social system developed during learning is to maximize cooperation and cooperation between students[8]. 
In addition to these three aspects, below will be discussed the input quality for various aspects of resource use, the desire to improve competence, and the environment among fellow students. Discussion of these three aspects can be seen in figure 2 .

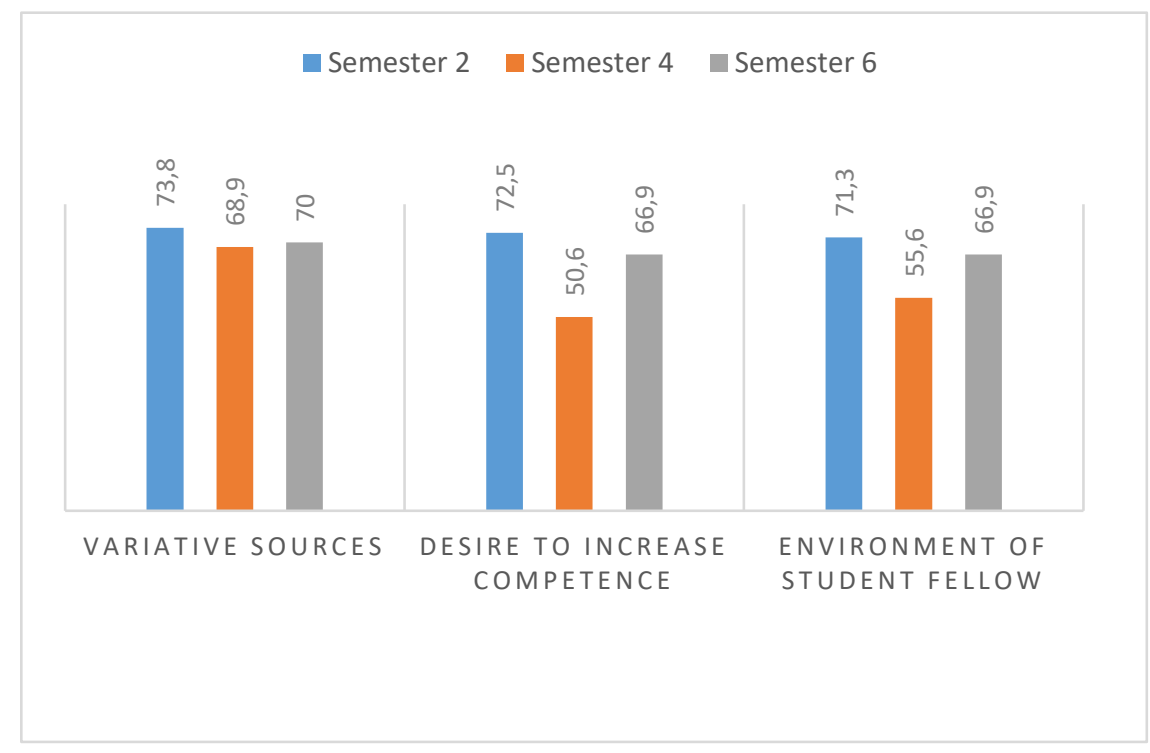

Figure 2. Data Results Aspects of Use of Variative Sources, Desire to Increase Competence, and Environment of Student Fellow

The varied aspects of resource use in the lecture process received the highest score of 73.8 with an average score of 70.9. The use of varied sources for early level students will be able to spur students to have a broad view of the sources of reading and reference writing, continuous motivation for students both personally and by lecturers to be able to improve their competencies also needs to be done. The use of varied sources is not only done by lecturers but students can also develop independently to be able to improve academic literacy competencies. This is in accordance with one of the standards in the ACRL Information Literacy Competency Standards for Higher Education, which is able to use new and previous information for planning and creating special results or performance[9].

The desire to improve academic literacy competence comes from the motivation of students themselves. Motivation is seen as a mental impulse that moves and directs human behavior, including learning behavior[10]. The obstacle that exists in this aspect is the feeling of laziness in students to continue to struggle with the science and field of scholarship that they are involved in. Unlike the case with the environmental aspects of fellow students in supporting the application of good academic literacy competencies by students. These aspects get the highest score of 71.3 with an average score of 64.6. The environment of fellow students can be an important role externally to implement and improve academic literacy competencies. Literacy activities will be easier to carry out in a mass manner both in private groups and together through certain institutional programs. The obstacle that arises in this aspect is that it is not conducive among students in supporting the application of academic literacy competencies. Indifference and dependence on students is an obstacle in working together to implement a friendly environment for literacy. 
In addition to these three aspects, below will be discussed for the availability of infrastructure facilities, the availability of journal access and the usefulness of the library. Discussion of these three aspects can be seen in figure 3 .

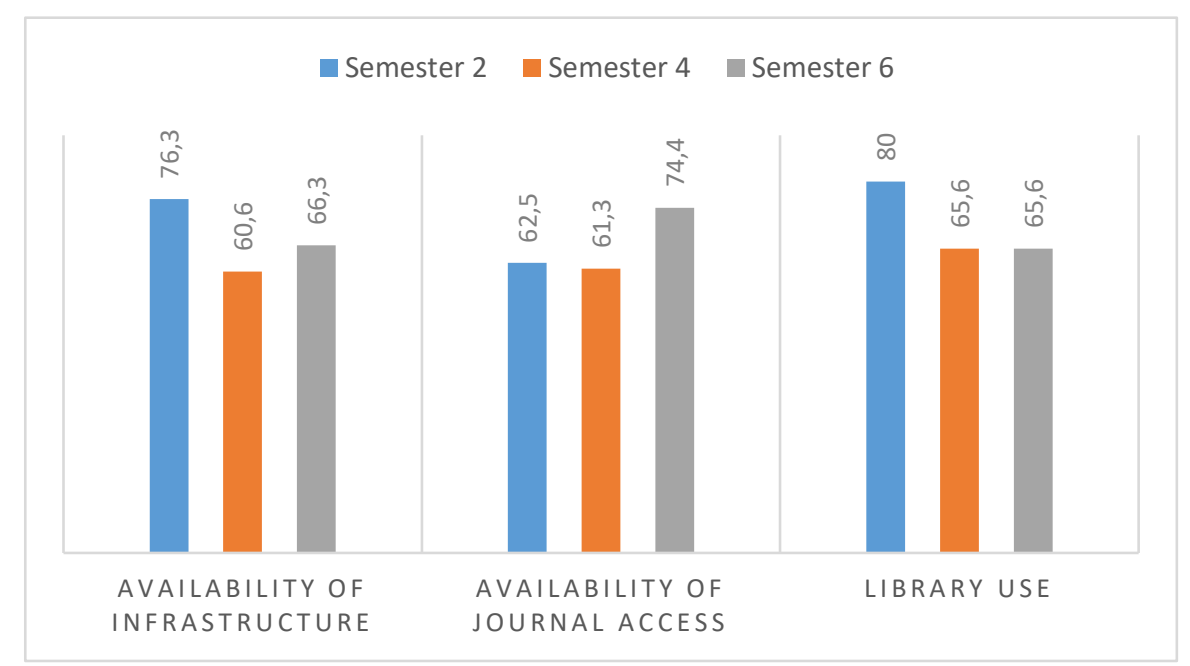

Figure 3. Data Results Aspects of Using Availability of Infrastructure, Availability of Journal Access, and Library Use

The aspect of the availability of infrastructure in supporting literacy activities in the Indonesian Language and Literature Department of Semarang State University obtained the highest score of 76.3 with an average score of 67.73. The availability of adequate facilities and infrastructure in supporting literacy activities will be able to have a major influence on student academic literacy competencies. Inadequate facilities and infrastructure are the use of internet networks on campus. Technological developments force students to be able to follow. In academic literacy competencies, digital literacy must also be applied properly and wisely so as not to adversely affect the competencies they have.

The availability aspect of journal access gets the highest score of 74.4 with an average score of 66.1. Availability of journal access is important for students to be able to facilitate lectures. Every college has facilitated access to journals for free and students can only use it maximally. The provision of electronic journals is not only limited to the library, but must consider several aspects, including: information updating, information relevance, completeness, and information content that can be accounted for[11]. Students have felt the usefulness of the library well to be able to support academic literacy competencies. The existence of a library is one of the important things in making it easier for students to attend lectures. Constraints in the procurement of libraries in the Indonesian Language and Literature Department of Semarang State University are the availability of inadequate internet networks for the application of digital literacy. 


\section{Conclusion}

The input quality of student literacy competencies gets sufficient results with an overall score of 69.5. Details of scores for each aspect are as follows (1) aspects of the role of the lecturer in the implementation of literacy activities get a score of $70,(2)$ the habitual aspects of conducting literacy activities score 69.6, (3) reciprocal giving of lecturers scores 73, 3, (4) the use of varied sources scores $70.9,(5)$ aspects of desire to improve reading and writing skills get a score of 63.3, (6) environmental aspects of fellow students in supporting the implementation of academic literacy competencies score $64.6,(7)$ the availability of infrastructure facilities has a score of $67.7,(8)$ the aspect of availability of journal access gets a score of 66.1, and (9) the aspect of library utilization gets a score of 80 . The quality of academic literacy competency input becomes a supporting quality both from internal and external both from students and from lecturers in carrying out the lecture process in college. 


\section{References}

[1] Harras, Kholid A.: Developing Children's Potential through Family Literacy Program, Articulate Journal Vol. 10 No. 1. (2011)

[2] Ristekdikti: Creative and Innovative in the Era of the Industrial Revolution 4.0. vol 8/1/2018 (2018). https://ristekdikti.go.id/wp-content/uploads/2018/05/Layout-Majalah-Ristekdikti-I-2018-UpdatePage-20180426.pdf

[3] Siroj, Muhammad Badrus. Development of a Center for Literacy Study Models to Improve the Reading Culture of Semarang State University Students. Journal. The 1st International Conference on Language, Literature, and Teaching. ISSN 2549-5607 (2018)

[4] Nurfadilah, Kurnia Dewi and Ida Zulaeha.: The Construction in Literacy Competence of Junior High School Students in Semarang is based on PISA Standards. Journal. Semarang: Select the Indonesian Language and Literature Education Journal. (2017).

[5] Johnspn, H, Watson, P.A, Delahunty,T., McSwiggen, P., \& Smith, T.: What it is They do: Differentiating Knowledge and Literacy Practices Across Content Disciplines. Journal. Journal of Adolescent \& Adult Literacy, 55, 100-109. (2011).

[6] Mulyatiningsih,, Endang: Process Evaluation of a Program. Jakarta: Bumi Aksara (2011).

[7] Chamalah, E., Agus N., Suminto A., \& Ida Z.: Local Literature in Coastal Islamic Education Alternative Subjects for Students of PBSI Unissula. ISET: Advances in Social Science, Education, and Humanities Research (ASSEHR). 247. 141-144. (2018).

[8] Zulaeha, I., Sofiah, Rahayu P., \& Tommi Y.: Learning Model for Text Exposition Writing on Learners in Visual, Auditory and Kinesthetic Learning Styles. ISET: Advances in Social Science, Education, and Humanities Research (ASSEHR), 247, 246-249 (2018).

[9] Nurtiar, Haryo: Tingkat Kemampuan Literasi Informasi Mahasiswa Skripsi: Studi Perbandingan FIK dan FKM UI. Tesis. Universitas Indonesia (2012).

[10] Dimyati and Mudjiono: Belajar dan Pembelajaran. Jakarta: Rineka Cipta (2009).

[11] Irianti and Hermini: Pengaruh Aksesbilitas dan Ketersediaan Jurnal Elektronik terhadap Kepuasan Pengguna Perpustakaan (2013). 